\title{
Synthesis, Physico-Chemical and Antimicrobial Screening Studies on 14 and 16-Membered Hexaazamacrocyclic Complexes Bearing Pendant Amine Groups
}

\author{
Mohammad Shakir,* Yasser Azim, Hamida T. N. Chishti, Nishat Begum, \\ Poonam Chingsubam and Mohammad Y. Siddiqi ${ }^{\#}$
}

Division of Inorganic Chemistry, Department of Chemistry, Aligarh Muslim University, Aligarh -202002, India

\begin{abstract}
Descrevem-se neste trabalho, a síntese e a caracterização de uma série de complexos hexaazamacrocíclicos com anéis de 14 e 16 membros, obtidos pela condensação de 1,2diaminometano ou 1,3-diaminopropano, formaldeído e hidrato de hidrazina, na presença de sais de metais do primeiro período de transição. Foram obtidos complexos dos tipos [ $\left.\mathrm{ML}^{1}\left(\mathrm{NO}_{3}\right)_{2}\right]$; $\left[\mathrm{CuL}^{1}\right]\left(\mathrm{NO}_{3}\right)_{2}$ e $\left[\mathrm{ML}^{2} \mathrm{Cl}_{2}\right] ;\left[\mathrm{CuL}^{2}\right] \mathrm{Cl}_{2}$, onde $\mathrm{M}=\mathrm{Co}(\mathrm{II}), \mathrm{Ni}(\mathrm{II})$ e $\mathrm{Zn}$ (II). As análises elementares, os espectros IV, de RMN de ${ }^{1} \mathrm{H}$, EPR e UV-Vis, assim como as medidas de susceptibilidade magnética e de condutividade, permitiram definir a geometria e a estereoquímica dos complexos. Os dados experimentais sugerem que todos os complexos exibem geometria octaédrica, exceto os de cobre, nos quais o centro metálico coordena-se aos quarto átomos de nitrogênio do ligante macrocíclico, em uma geometria quadrática plana. A atividade desses compostos foi avaliada in vitro contra vários tipos de fungos e bactérias e mostraram-se ativos na concentração de $5 \mathrm{mg}$ $\mathrm{mL}^{-1}$.
\end{abstract}

The synthesis and characterization of a series of 14 and 16-membered hexaazamacrocyclic complexes, which were obtained via template condensation of 1,2- diaminoethane or 1,3diaminopropane, formaldehyde and hydrazine hydrate in the presence of first row transition metal salts are reported. Complexes of the types, $\left[\mathrm{ML}^{1}\left(\mathrm{NO}_{3}\right)_{2}\right] ;\left[\mathrm{CuL}^{1}\right]\left(\mathrm{NO}_{3}\right)_{2}$ and $\left[\mathrm{ML}^{2} \mathrm{Cl}_{2}\right]$; $\left[\mathrm{CuL}^{2}\right] \mathrm{Cl}_{2}$ (where $\mathrm{M}=\mathrm{Co}(\mathrm{II}), \mathrm{Ni}(\mathrm{II})$ and $\mathrm{Zn}(\mathrm{II})$ ), were obtained. Elemental analyses, IR spectra, ${ }^{1} \mathrm{H}$ NMR, EPR, UV-Vis, magnetic susceptibility and conductivity measurements have ascertained the overall geometry and stereochemistry of the complexes. An octahedral geometry has been suggested for all the complexes, except for copper compounds, in which the metal centre coordinates to the four nitrogen atoms of macrocyclic ligand in a square planar fashion. These complexes were screened against different fungi and bacteria in vitro and were found to be potentially active in the concentration $5 \mathrm{mg} \mathrm{mL}^{-1}$.

Keywords: formaldehyde, hydrazine hydrate, hexaazamacrocylic complexes, spectral studies template condensation

\section{Introduction}

The chemistry of macrocyclic compounds or complexes is a rapidly developing area in view of their various applications such as therapeutic agents, ${ }^{1}$ magnetic resonance imaging (MRI) contrast agents, ${ }^{2,3}$ as luminescent sensors, ${ }^{4}$ as artificial restriction enzymes for cleaving DNA and RNA, ${ }^{5-7}$ etc. Recently, ${ }^{8-10}$ there has been considerable interest in preparation of macrocyclic complexes of the transition metals, which

\footnotetext{
* e-mail: shakirnafees@yahoo.co.in

\# Present address: King Saud University, College of Sciences, Riyadh, Saudi Arabia
}

have a variety of functional groups on the periphery of the macrocyclic rings. A number of papers have described the additional functionality of the macrocyclic complexes. For example, Sibert et al. synthesized and studied a class of isopropyl and isobutyl-appended macrocycles and their metal complexes that inhibit the growth of mouse leukemia cells (L1210) in micromolar to submicromolar concentrations. ${ }^{1}$ Tweedy et al. studied a macrocycle with a pendant pyridyl function, which is sterically restricted in its binding to the metal centre. ${ }^{11}$ Wade and Hancock reported the preparation of reinforced macrocycles, one example of which has a primary amine function capable of undergoing further reaction. ${ }^{12}$ 
Many macrocyclic complexes have been synthesized by the template condensation of amines with aldehydes in the presence of metal ions and in particular, formaldehyde has been utilized for cyclization to link two amine moieties. ${ }^{13-17}$

Herein, we report the synthesis of a series of 14 and 16-membered pendant-armed hexaazamacrocyclic complexes obtained by template condensation of 1,2diaminoethane or 1,3-diaminopropane and hydrazine by formaldehyde in presence of transition metal ions.

\section{Results and Discussion}

A series of 14 and 16-membered hexaazamacrocyclic complexes of types, $\left[\mathrm{ML}^{1}\left(\mathrm{NO}_{3}\right)_{2}\right] ;\left[\mathrm{CuL}^{1}\right]\left(\mathrm{NO}_{3}\right)_{2}$ and $\left[\mathrm{ML}^{2} \mathrm{Cl}_{2}\right] ;\left[\mathrm{CuL}^{2}\right] \mathrm{Cl}_{2}$, where $\mathrm{M}=\mathrm{Co}(\mathrm{II}), \mathrm{Ni}(\mathrm{II})$ and $\mathrm{Zn}(\mathrm{II})$, have been synthesized by template condensation procedure. 1,2-diaminoethane or 1,3-diaminopropane and hydrazine were condensed in the presence of first row transition metal ions by formaldehyde in 2:2:4:1 molar ratio as shown in Scheme 1. All the complexes are microcrystalline, stable in air and are soluble in DMF, DMSO and THF. However all efforts failed to grow single crystal suitable for X-ray crystallography.

These complexes were investigated and characterized by IR, ${ }^{1} \mathrm{H}$ NMR, electronic spectra, magnetic susceptibility and EPR studies. Elemental analyses (Table 1) agree well with the proposed structures of the complexes. The low molar conductance values of all the complexes in DMSO at room temperature support the non-ionic nature of the complexes except for the copper complexes, which are ionic.

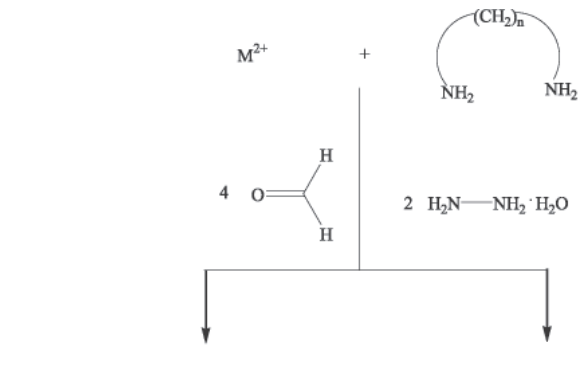

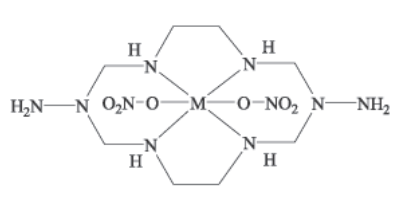

$\left[\mathrm{ML}^{1}\left(\mathrm{NO}_{3}\right)_{2}\right]$

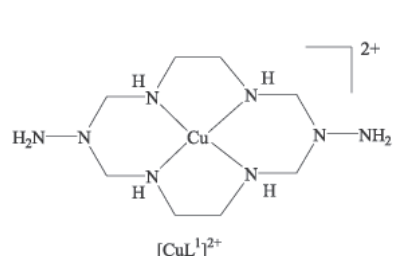

$\left[\mathrm{CuL}^{1}\right]^{2+}$

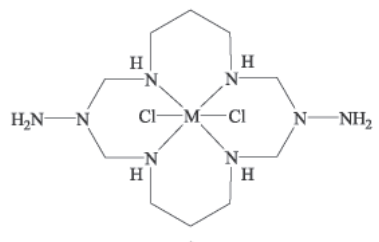

$\left[\mathrm{ML}^{2} \mathrm{Cl}_{2}\right]$

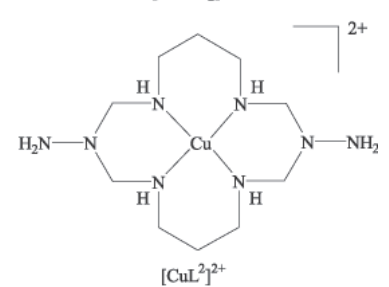

Where, $\mathrm{M}=\mathrm{Co}(\mathrm{II}), \mathrm{Ni}(\mathrm{II})$ and $\mathrm{Zn}(\mathrm{II})$

Scheme 1. Synthetic scheme and the suggested structures.

IR spectra

The IR spectra (Figure 1) of the complexes exhibit characteristic bands of the expected functional groups and the relevant data are listed in Table 2. The IR spectra of the complexes show the presence of sharp band in the 3210$3260 \mathrm{~cm}^{-1}$ region, assignable to the coordinated secondary amino stretching mode, indicating that the proposed condensation has occurred. ${ }^{18}$ The absence of a band in the

Table 1. Formula weight, melting point, yield (\%), color, analytical data and molar conductance for the complexes

\begin{tabular}{|c|c|c|c|c|c|c|c|c|c|c|}
\hline \multirow[t]{2}{*}{ Complex } & \multirow[t]{2}{*}{ F.W. } & \multirow{2}{*}{$\begin{array}{l}\mathrm{mp} \\
\left({ }^{\circ} \mathrm{C}\right)\end{array}$} & \multirow{2}{*}{$\begin{array}{l}\text { Yield } \\
(\%)\end{array}$} & \multirow[t]{2}{*}{ Color } & \multicolumn{5}{|c|}{ Found (Calc.)\% } & \multirow{2}{*}{$\begin{array}{l}\text { Molar Conductance } \\
\qquad\left(\mathrm{cm}^{2} \Omega^{-1} \mathrm{~mol}^{-1}\right)\end{array}$} \\
\hline & & & & & M & $\mathrm{Cl}$ & $\mathrm{C}$ & $\mathrm{H}$ & $\mathrm{N}$ & \\
\hline \multirow{16}{*}{$\begin{array}{l}{\left[\mathrm{CoL}^{1}\left(\mathrm{NO}_{3}\right)_{2}\right]} \\
\mathrm{C}_{8} \mathrm{H}_{24} \mathrm{CoN}_{10} \mathrm{O}_{6} \\
{\left[\mathrm{CoL}^{2} \mathrm{Cl}_{2}\right]} \\
\mathrm{C}_{10} \mathrm{H}_{28} \mathrm{Cl}_{2} \mathrm{CoN}_{8} \\
{\left[\mathrm{NiL}^{1}\left(\mathrm{NO}_{3}\right)_{2}\right]} \\
\mathrm{C}_{8} \mathrm{H}_{24} \mathrm{~N}_{10} \mathrm{NiO}_{6} \\
{\left[\mathrm{NiL}^{2} \mathrm{Cl}_{2}\right]} \\
\mathrm{C}_{10} \mathrm{H}_{28} \mathrm{Cl}_{2} \mathrm{~N}_{8} \mathrm{Ni} \\
{\left[\mathrm{CuL}^{1}\right]\left(\mathrm{NO}_{3}\right)_{2}} \\
\mathrm{C}_{8} \mathrm{H}_{24} \mathrm{CuN}_{10} \mathrm{O}_{6} \\
{\left[\mathrm{CuL}^{2}\right] \mathrm{Cl}_{2}} \\
\mathrm{C}_{10} \mathrm{H}_{28} \mathrm{Cl}_{2} \mathrm{CuN}_{8} \\
{\left[\mathrm{ZnL}^{1}\right]\left(\mathrm{NO}_{3}\right)_{2}} \\
\mathrm{C}_{8} \mathrm{H}_{24} \mathrm{~N}_{10} \mathrm{O}_{6} \mathrm{Zn} \\
{\left[\mathrm{ZnL}^{2} \mathrm{Cl}_{2}\right]} \\
\mathrm{C}_{10} \mathrm{H}_{28} \mathrm{Cl}_{2} \mathrm{~N}_{8} \mathrm{Zn}\end{array}$} & 415.27 & 253 & 50 & Brown & 13.89 & - & 22.94 & 5.73 & 33.60 & 20 \\
\hline & & & & & (14.19) & & (23.14) & $(5.83)$ & (33.73) & \\
\hline & 390.22 & 252 & 55 & Brown & 15.00 & 18.27 & 30.65 & 7.10 & 28.66 & 22 \\
\hline & & & & & (15.10) & (18.17) & (30.78) & (7.23) & $(28.72)$ & \\
\hline & 415.03 & 254 & 60 & Light & 13.90 & - & 23.03 & 5.79 & 33.56 & 30 \\
\hline & & & & Purple & (14.10) & & $(23.15)$ & $(5.83)$ & $(33.75)$ & \\
\hline & 389.98 & 245 & 56 & Purple & 14.89 & 18.01 & 30.57 & 7.35 & 28.84 & 28 \\
\hline & & & & & (15.00) & (18.18) & $(30.80)$ & (7.24) & (28.73) & \\
\hline & 419.89 & 250 & 49 & Green & 15.15 & - & 22.90 & 5.81 & 33.22 & 98 \\
\hline & & & & & (15.13) & & $(22.88)$ & $(5.76)$ & (33.36) & \\
\hline & 394.83 & 255 & 51 & Dark & 15.93 & 17.84 & 30.20 & 7.26 & 28.49 & 105 \\
\hline & & & & Green & (16.10) & (17.96) & $(30.42)$ & (7.15) & (28.38) & \\
\hline & 421.73 & 260 & 55 & Colourless & 15.30 & - & 22.61 & 5.65 & 33.10 & 25 \\
\hline & & & & & $(15.51)$ & & (22.78) & $(5.74)$ & $(33.21)$ & \\
\hline & 396.68 & 255 & 54 & Colourless & 16.35 & 17.69 & 30.42 & 7.20 & 28.45 & 21 \\
\hline & & & & & (16.48) & (17.87) & (30.28) & (7.11) & $(28.25)$ & \\
\hline
\end{tabular}




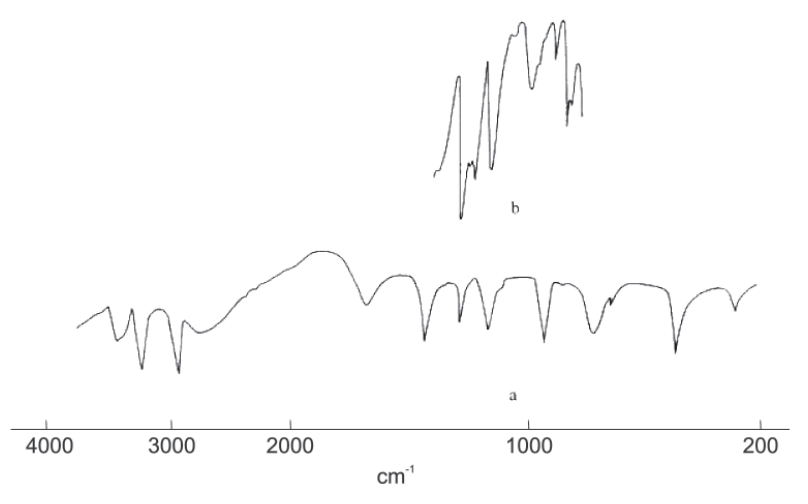

Figure 1. The IR spectrum of (a) $\left[\mathrm{CoL}^{2} \mathrm{Cl}_{2}\right]$ and (b) additional bands of monodentate nitrate group.

$1720-1740 \mathrm{~cm}^{-1}$ region, characteristic $v(\mathrm{C}=\mathrm{O})$ of aldehydic moiety, further confirms the condensation. The complexes also show medium intensity bands of pendant primary amine groups appearing in the $3400-3475 \mathrm{~cm}^{-1}$ region. All the complexes show bands in the $1140-1180 \mathrm{~cm}^{-1}$ and 2930-2960 $\mathrm{cm}^{-1}$ regions, which may be assigned to $v(\mathrm{C}-\mathrm{N})$ and $v(\mathrm{C}-\mathrm{H})$, respectively. The sharp band in the 410-450 $\mathrm{cm}^{-1}$ region for all the complexes can be assigned to $v(\mathrm{M}-$ N). ${ }^{15}$ However, a sharp band appearing around 947-970 $\mathrm{cm}^{-1}$ in all the complexes may be attributed to $\mathrm{N}-\mathrm{N}$ stretching mode. ${ }^{19}$ The coordination of nitrato and chloro groups have been ascertained by the appearance of bands in the $230-240 \mathrm{~cm}^{-1}$ and $270-300 \mathrm{~cm}^{-1}$ regions, which may reasonably be assigned to $v(\mathrm{M}-\mathrm{O})$ of the $\mathrm{O}-\mathrm{NO}_{2}$ group and $v(\mathrm{M}-\mathrm{CI})$ in $\left[\mathrm{ML}^{1}\left(\mathrm{NO}_{3}\right)_{2}\right]$ and $\left[\mathrm{ML}^{2} \mathrm{Cl}_{2}\right]$ complexes respectively. The spectra of the complexes show further bands in 1230-1260, 1040-1080 and 870-890 $\mathrm{cm}^{-1}$ regions, which are consistent with monodentate coordination of the nitrato group. ${ }^{20}$

\section{${ }^{1} H$ NMR spectra}

The ${ }^{1} \mathrm{H}$ NMR data for $\mathrm{Zn}$ (II) complexes show a multiplet in the $\delta$ 7.10-7.16 region, which may be assigned to the secondary amino protons $(\mathrm{C}-\mathrm{NH}-\mathrm{C} ; 4 \mathrm{H})$ of $1,2-$ diaminoethane and 1,3-diaminopropane moieties. However, a singlet in the $\delta$ 5.10-5.18 region may be attributed to the pendant primary amino protons $\left(\mathrm{N}-\mathrm{NH}_{2} ; 4 \mathrm{H}\right)$. A multiplet observed in the $\delta$ 2.70-2.96 region corresponds to methylene protons $\left(\mathrm{N}-\mathrm{CH}_{2}-\mathrm{C} ; 8 \mathrm{H}\right)$ adjacent to the nitrogen atom of the amino moiety. Another multiplet, at $\delta 1.98$, may reasonably be assigned to the methylene protons $\left(\mathrm{C}-\mathrm{CH}_{2}-\right.$ $\mathrm{C} ; 4 \mathrm{H})$ of the 1,3-diaminopropane moiety. A mulitplet observed in the $\delta$ 3.15-3.25 region may be attributed to the methylene protons $\left(\mathrm{N}-\mathrm{CH}_{2}-\mathrm{N} ; 8 \mathrm{H}\right)$.
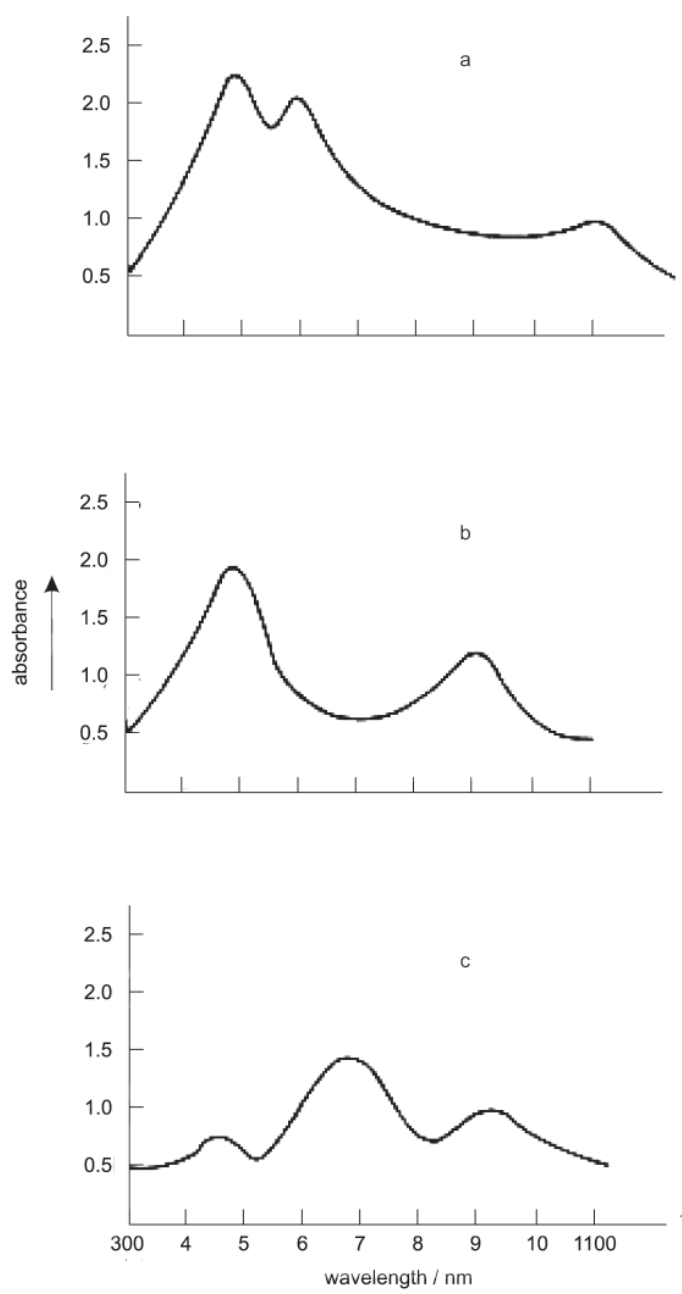

Figure 2. The electronic electronic spectra of (a) $\left[\mathrm{CoL}^{1}\left(\mathrm{NO}_{3}\right)_{2}\right]$ (b) $\left[\mathrm{NiL}^{1}\left(\mathrm{NO}_{3}\right)_{2}\right]$ and $(\mathrm{c})\left[\mathrm{CuL}^{1}\right]\left(\mathrm{NO}_{3}\right)_{2}$.

Table 2. IR vibrational frequencies $\left(\mathrm{cm}^{-1}\right)$ of the complexes

\begin{tabular}{lcccccr}
\hline Complex & $v(\mathrm{~N}-\mathrm{H})$ & $v(\mathrm{~N}-\mathrm{N})$ & $v(\mathrm{C}-\mathrm{N})$ & $v(\mathrm{M}-\mathrm{N})$ & $v(\mathrm{C}-\mathrm{H})$ & $v(\mathrm{M}-\mathrm{O})$ \\
\hline$\left[\mathrm{CoL}^{1}\left(\mathrm{NO}_{3}\right)_{2}\right]$ & $3210 \mathrm{~s}$ & $952 \mathrm{~s}$ & $1175 \mathrm{~m}$ & $415 \mathrm{~s}$ & $2960 \mathrm{~s}$ & $237 \mathrm{~m}$ \\
{$\left[\mathrm{CoL}^{2} \mathrm{Cl}_{2}\right]$} & $3220 \mathrm{~s}$ & $947 \mathrm{~s}$ & $1180 \mathrm{~m}$ & $425 \mathrm{~s}$ & $2955 \mathrm{~s}$ & - \\
{$\left[\mathrm{NiL}^{1}\left(\mathrm{NO}_{3}\right)_{2}\right]$} & $3235 \mathrm{~s}$ & $964 \mathrm{~s}$ & $1170 \mathrm{~m}$ & $435 \mathrm{~s}$ & $2950 \mathrm{~s}$ & $230 \mathrm{~m}$ \\
{$\left[\mathrm{NiL}^{2} \mathrm{Cl}_{2}\right]$} & $3230 \mathrm{~s}$ & $959 \mathrm{~s}$ & $1190 \mathrm{~m}$ & $440 \mathrm{~s}$ & $2945 \mathrm{~s}$ & - \\
{$\left[\mathrm{CuL}^{1}\right]\left(\mathrm{NO}_{3}\right)_{2}$} & $3248 \mathrm{~s}$ & $960 \mathrm{~s}$ & $1165 \mathrm{~m}$ & $442 \mathrm{~s}$ & $2930 \mathrm{~s}$ & - \\
{$\left[\mathrm{CuL}^{2}\right] \mathrm{Cl}_{2}$} & $3250 \mathrm{~s}$ & $967 \mathrm{~s}$ & $1160 \mathrm{~m}$ & $445 \mathrm{~s}$ & $2935 \mathrm{~s}$ & - \\
{$\left[\mathrm{ZnL}^{1}\left(\mathrm{NO}_{3}\right)_{2}\right]$} & $3254 \mathrm{~s}$ & $970 \mathrm{~s}$ & $1150 \mathrm{~m}$ & $440 \mathrm{~s}$ & $2960 \mathrm{~s}$ & $240 \mathrm{~m}$ \\
{$\left[\mathrm{ZnL}^{2} \mathrm{Cl}_{2}\right]$} & $3260 \mathrm{~s}$ & $965 \mathrm{~s}$ & $1145 \mathrm{~m}$ & $450 \mathrm{~s}$ & $2953 \mathrm{~s}$ & - \\
\hline
\end{tabular}

s: strong intensity band; m: medium intensity band. 
Table 3. Magnetic moments, electronic spectral data and assignments and EPR data of the complexes

\begin{tabular}{|c|c|c|c|c|c|c|}
\hline \multirow[t]{2}{*}{ Complex } & \multirow[t]{2}{*}{$\mu_{\text {eff }}$ (B.M.) } & \multirow[t]{2}{*}{ Band position $\left(\mathrm{cm}^{-1}\right)$} & \multirow[t]{2}{*}{ Assignment } & \multicolumn{3}{|c|}{ EPR Parameters } \\
\hline & & & & $\mathrm{g}_{\|}$ & $g_{\perp}$ & G \\
\hline \multirow{3}{*}[\mathrm{CoL}^{1}(\mathrm{NO}_{3})_{2}]{} & 4.54 & 21,600 & ${ }^{4} \mathrm{~T}_{1} \mathrm{~g}(\mathrm{~F}) \rightarrow{ }^{4} \mathrm{~T}_{1} \mathrm{~g}(\mathrm{P})$ & - & - & - \\
\hline & & 16,750 & ${ }^{4} \mathrm{~T}_{1} \mathrm{~g}(\mathrm{~F}) \rightarrow{ }^{4} \mathrm{~A}_{2} \mathrm{~g}(\mathrm{~F})$ & & & \\
\hline & & 9090 & $\left.{ }^{4} \mathrm{~T}_{1} \mathrm{~g}(\mathrm{~F})\right) \rightarrow{ }^{4} \mathrm{~T}_{2} \mathrm{~g}(\mathrm{~F})$ & & & \\
\hline \multirow[t]{3}{*}[\mathrm{CoL}^{2}\mathrm{Cl}_{2}]{} & 4.56 & 21,850 & ${ }^{4} \mathrm{~T}_{1} \mathrm{~g}(\mathrm{~F}) \rightarrow{ }^{4} \mathrm{~T}_{1} \mathrm{~g}(\mathrm{P})$ & - & - & - \\
\hline & & 17,000 & ${ }^{4} \mathrm{~T}_{1} \mathrm{~g}(\mathrm{~F}) \rightarrow{ }^{4} \mathrm{~A}_{2} \mathrm{~g}(\mathrm{~F})$ & & & \\
\hline & & 9000 & $\left.{ }^{4} \mathrm{~T}_{1} \mathrm{~g}(\mathrm{~F})\right) \rightarrow{ }^{4} \mathrm{~T}_{2} \mathrm{~g}(\mathrm{~F})$ & & & \\
\hline \multirow{2}{*}[\mathrm{NiL}^{1}(\mathrm{NO}_{3})_{2}]{} & 3.11 & 17,600 & ${ }^{3} \mathrm{~A}_{2} \mathrm{~g}(\mathrm{~F}) \rightarrow{ }^{3} \mathrm{~T}_{1} \mathrm{~g}(\mathrm{P})$ & - & - & - \\
\hline & & 11,200 & ${ }^{3} \mathrm{~A}_{2} \mathrm{~g}(\mathrm{~F}) \rightarrow{ }^{3} \mathrm{~T}_{2} \mathrm{~g}(\mathrm{~F})$ & & & \\
\hline \multirow{2}{*}[\mathrm{NiL}^{2}\mathrm{Cl}_{2}]{} & 3.08 & 17,500 & ${ }^{3} \mathrm{~A}_{2} \mathrm{~g}(\mathrm{~F}) \rightarrow{ }^{3} \mathrm{~T} g(\mathrm{P})$ & - & - & - \\
\hline & & 11,400 & ${ }^{3} \mathrm{~A}_{2} \mathrm{~g}(\mathrm{~F}) \rightarrow{ }^{3} \mathrm{~T}_{2} \mathrm{~g}(\mathrm{~F})$ & & & \\
\hline \multirow{3}{*}[\mathrm{CuL}^{1}]{$\left(\mathrm{NO}_{3}\right)_{2}$} & 1.85 & 21,450 & ${ }^{2} \mathrm{~B}_{1} \mathrm{~g} \rightarrow{ }^{2} \mathrm{Eg}$ & 2.15 & 2.04 & 3.75 \\
\hline & & 16,050 & ${ }^{2} \mathrm{~B}_{1} \mathrm{~g} \rightarrow{ }^{2} \mathrm{~A}_{1} \mathrm{~g}$ & & & \\
\hline & & 12,200 & ${ }^{2} \mathrm{~B}_{1} \mathrm{~g} \rightarrow{ }^{2} \mathrm{~B}_{2} \mathrm{~g}$ & & & \\
\hline \multirow[t]{3}{*}[\mathrm{CuL}^{2}]{$\mathrm{Cl}_{2}$} & 1.87 & 21,700 & ${ }^{2} \mathrm{~B}_{1} \mathrm{~g} \rightarrow{ }^{2} \mathrm{Eg}$ & 2.18 & 2.05 & 3.60 \\
\hline & & 16,000 & ${ }^{2} \mathrm{~B}_{1} \mathrm{~g} \rightarrow{ }^{2} \mathrm{~A}_{1} \mathrm{~g}$ & & & \\
\hline & & 12,650 & ${ }^{2} \mathrm{~B}_{1} \mathrm{~g} \rightarrow{ }^{2} \mathrm{~B}_{2} \mathrm{~g}$ & & & \\
\hline
\end{tabular}

\section{Electronic spectra and magnetic data}

In the case of the cobalt (II) complexes (Figure 2a), the electronic spectra (Table 3) showed three bands in the 9,090-9,000, 16,750-17,000 and 21,600-21,850 $\mathrm{cm}^{-1}$ regions assignable to the ${ }^{4} \mathrm{~T}_{1} \mathrm{~g}(\mathrm{~F}) \rightarrow{ }^{4} \mathrm{~T}_{2} \mathrm{~g}(\mathrm{~F}),{ }^{4} \mathrm{~T}_{1} \mathrm{~g}(\mathrm{~F}) \rightarrow$ ${ }^{4} \mathrm{~A}_{2} \mathrm{~g}(\mathrm{~F})$ and ${ }^{4} \mathrm{~T}_{1} \mathrm{~g}(\mathrm{~F}) \rightarrow{ }^{4} \mathrm{~T}_{1} \mathrm{~g}(\mathrm{P})$ transitions, respectively, corresponding to the octahedral geometry around the cobalt (II) ion. ${ }^{21,22}$ The observed magnetic moment values for the cobalt complexes in the 4.54-4.56 B.M. range correspond to high spin state and further supports the octahedral geometry around cobalt (II) ion.

The electronic spectra of the nickel (II) complexes (Figure 2b) show two distinct bands in the 11,200-11,400 and $17,500-17,600 \mathrm{~cm}^{-1}$ range comparable to the spectral features of octahedral nickel (II) complexes, corresponding to ${ }^{3} \mathrm{~A}_{2} \mathrm{~g}(\mathrm{~F}) \rightarrow{ }^{3} \mathrm{~T}_{1} \mathrm{~g}(\mathrm{~F})$ and ${ }^{3} \mathrm{~A}_{2} \mathrm{~g}(\mathrm{~F}) \rightarrow{ }^{3} \mathrm{~T}_{1} \mathrm{~g}(\mathrm{P})$ transitions, respectively. ${ }^{23}$ The observed magnetic moment in the 3.083.11 B.M range further confirms the above geometry.

The electronic spectra of the copper (II) complexes (Figure 2c) show a broad band centered at ca. $16,000 \mathrm{~cm}^{-1}$ assignable to ${ }^{2} \mathrm{~B}_{1} \mathrm{~g} \rightarrow{ }^{2} \mathrm{~A}_{1} \mathrm{~g}$ transitions. However, two weak shoulders appearing in the 12,200-12,650 and 21,450-21,700 $\mathrm{cm}^{-1}$ the regions may be ascribed to ${ }^{2} \mathrm{~B}_{1} \mathrm{~g} \rightarrow{ }^{2} \mathrm{~B}_{2} \mathrm{~g}$ and ${ }^{2} \mathrm{~B}_{1} \mathrm{~g} \rightarrow{ }^{2} \mathrm{Eg}$ transitions, respectively, suggesting a square planar geometry around the copper (II) ion. ${ }^{22}$ The observed magnetic moments of the copper (II) complexes fall in the 1.85-1.87 B.M. range.

$E P R$

The EPR spectra (Table 3) of the powdered solid copper (II) macrocyclic complexes were recorded at room temperature and their $\mathrm{g}_{\|}$and $\mathrm{g}_{\perp}$ values have been calculated. Both complexes exhibit a similar single broad absorption band. The absence of hyperfine lines in these complexes may be due to the strong dipolar and exchange interactions between the copper (II) ions in the unit cell. ${ }^{24}$ The calculated $\mathrm{g}_{\|}$and $\mathrm{g}_{\perp}$ values appeared in the 2.15-2.18 and 2.04-2.05 regions, respectively, which support the fact that ${ }^{2} \mathrm{~B}_{1} \mathrm{~g}$ is the ground state having an unpaired electron in the $d_{x^{2}-y^{2}}$ orbitals. ${ }^{25}$ Both complexes show $\mathrm{g}_{\|}<2.3$. It should be noted that for an ionic environment, $\mathrm{g}_{\|}>2.3$, whereas for a covalent environment $\mathrm{g}_{\|}<2.3$, indicating that the present complexes exhibit appreciable covalent nature. The $g$ values are related by the expression $G=\left(g_{\|}-2\right) /$ $\left(g_{\perp}-2\right)$, and lie in the range 3.60-3.75, indicating a significant exchange interaction among the $\mathrm{Cu}^{+2}$ ions in these complexes, as the $\mathrm{G}$ values are less than $4 .^{26}$

\section{Antimicrobial screening}

The antimicrobial activity of the 14 and 16membered hexaazamacrocyclic complexes of $\mathrm{Co}$ (II), $\mathrm{Ni}(\mathrm{II}), \mathrm{Cu}(\mathrm{II})$ and $\mathrm{Zn}(\mathrm{II})$ was determined on Candida albicans, Cryptococcus neoformans, Salmonella typhimurium and Escherichia coli respectively, by using agar well diffusion method. ${ }^{27,28}$ These compounds exhibited activity at the concentration dose of $5 \mathrm{mg} \mathrm{mL}$, as shown in Figure 3 and 4, which is comparable to that of tetradentate 12 -membered macrocyclic compounds, shown to have antimicrobial activity against various pathogens, by disc diffusion technique. ${ }^{29}$ 


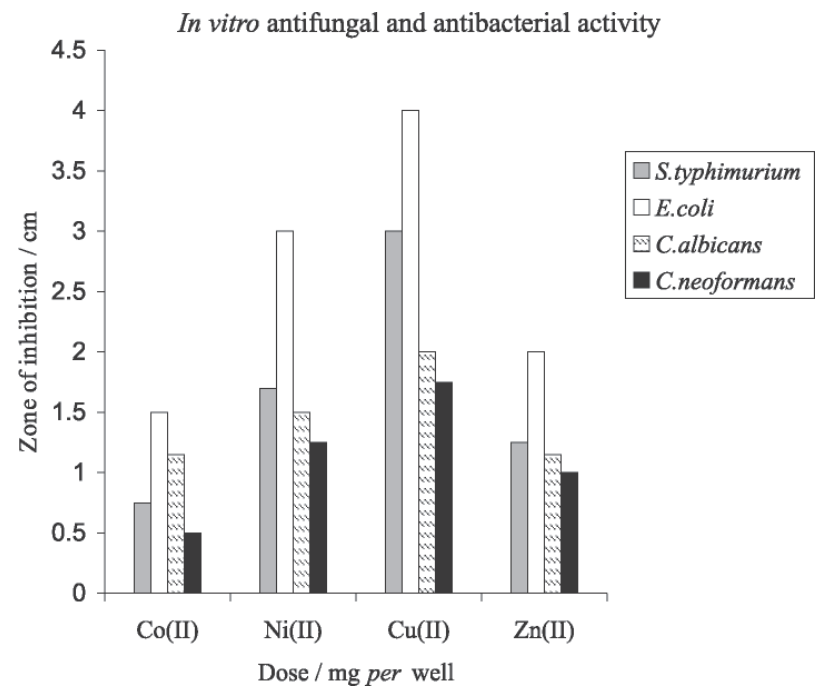

Figure 3. The antimicrobial screening of 14-membered hexaazamacrocyclic complexes.

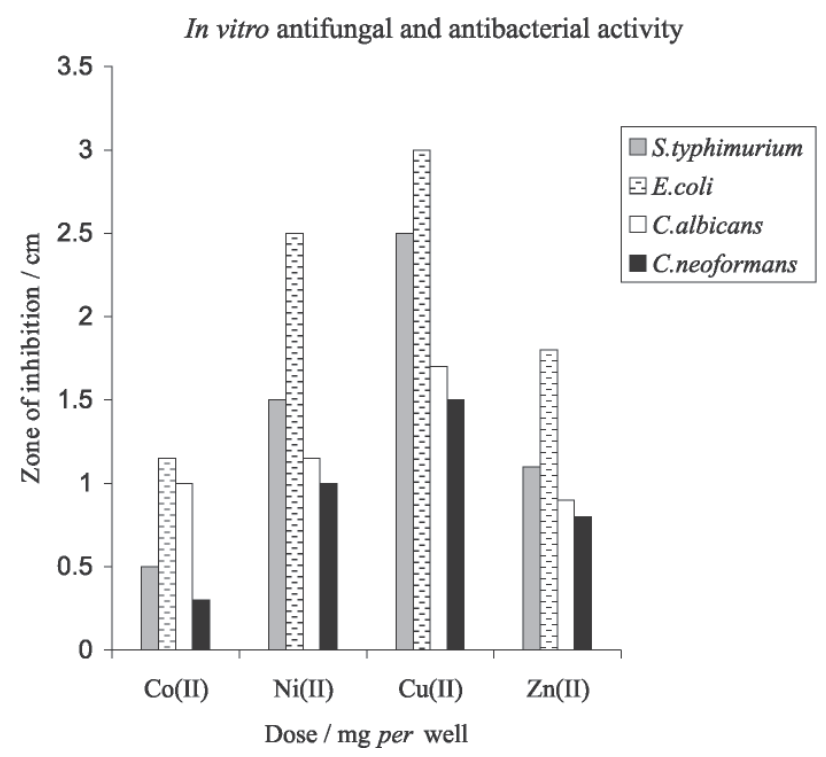

Figure 4. The antimicrobial screening of 16-membered hexaazamacrocyclic complexes.

\section{Conclusions}

A series of 14 and 16-membered $\mathrm{N}_{6}$ macrocyclic complexes has been synthesized via templation procedure by reacting 1,2-diaminoethane or 1,3-diaminopropane, hydrazine hydrate and formaldehyde. The formation of the proposed macrocyclic framework has been inferred by the appearance of secondary amine bands in the IR and corresponding proton resonance signals in the ${ }^{1} \mathrm{H}$ NMR spectral studies. The confirmation regarding the stoichiometry with respect to metal and over-all geometry around each metal ion has been deduced from the molar conductivity,
UV-Visible and EPR spectral studies. Preliminary studies of the antimicrobial activity of these complexes indicate that they are active against a series of pathogens.

\section{Experimental}

Materials

The metal salts $\mathrm{MX}_{2} \cdot 6 \mathrm{H}_{2} \mathrm{O}\left(\mathrm{M}=\mathrm{Co}^{2+}\right.$ and $\mathrm{Ni}^{2+} ; \mathrm{X}=$ $\left.\mathrm{Cl}^{-}, \mathrm{NO}_{3}^{-}\right)$(E. Merck), $\mathrm{CuX} \mathrm{XH}_{2} \mathrm{O}\left(\mathrm{X}=\mathrm{Cl}, \mathrm{NO}_{3} ; \mathrm{n}=2\right.$, 3) (E. Merck), $\mathrm{ZnCl}_{2}, \mathrm{Zn}\left(\mathrm{NO}_{3}\right)_{2} \cdot 6 \mathrm{H}_{2} \mathrm{O}$ (E. Merck) were commercially available as pure samples. The chemicals, hydrazine hydrate $98 \%$ (Aldrich), formaldehyde $37 \%$ aqueous solution (E. Merck), 1,2-diaminoethane (E. Merck) and 1,3- diaminopropane (E. Merck) were used as received. Methanol (AR grade) used as solvent without further purification.

Synthesis of Dinitrato $(1,3,5,8,10,12$-hexaaza-3,10-N,N'diaminocyclodecatetrane) metal (II) $\left[\mathrm{ML}^{1}\left(\mathrm{NO}_{3}\right)_{2}\right]\{\mathrm{M}=\mathrm{Co}$ (II), Ni(II) and Zn(II)\}; Synthesis of $(1,3,5,8,10,12$ hexaaza-3,10-N,N'-diaminocyclodecatetrane) copper (II) nitrate $\left[\mathrm{CuL}^{1}\right]\left(\mathrm{NO}_{3}\right)_{2}$

To a stirring methanolic $(50 \mathrm{~mL})$ solution of metal salt $(0.01 \mathrm{~mol})$ containing 1,2 - diaminoethane $(0.02 \mathrm{~mol}$; $1.4 \mathrm{~mL}$ ) was added, dropwise, a solution of hydrazine hydrate $98 \%(0.02 \mathrm{~mol} ; 1.0 \mathrm{~mL})$ in methanol $(25 \mathrm{~mL})$ and $37 \%$ aqueous solution of formaldehyde solution (0.04 mol; $2.9 \mathrm{~mL})$ in methanol $(25 \mathrm{~mL})$ simultaneously. The resulting mixture was refluxed for 15 hours leading to the solid product. The solid product thus formed was filtered off washed several times with methanol and dried in vacuo.

Synthesis of Dichloro (1,3,5,9,11,13-hexaaza-3,11-N,N'diaminocyclodecahexane metal (II) $\left[\mathrm{ML}^{2} \mathrm{Cl}_{2}\right]\{\mathrm{M}=\mathrm{Co}$ (II), Ni(II) and Zn(II)\}; Synthesis of $(1,3,5,9,11,13$ hexaaza-3,11-N,N'-diaminocyclodecahexane) copper (II) chloride $\left[\mathrm{CuL}^{2}\right] \mathrm{Cl}_{2}$

The procedure was similar to the one mentioned above, where 1,3 -diaminopropane $(0.02 \mathrm{~mol} ; 1.69 \mathrm{~mL})$ and metal chloride salts were used instead of 1,2-diaminoethane and metal nitrate salts.

\section{Antimicrobial screening}

Determination of Minimum Inhibition Concentration (MIC). MIC's of 14 and 16-membered hexaazamacrocyclic complexes were determined by broad dilution technique as described by NCCLS. ${ }^{28}$ 
Final concentration of complexes ranged from 1.5-5 $\mathrm{mg} \mathrm{mL} \mathrm{m}^{-1}$. MIC microtitre plate of fungal strains were incubated aerobically at $30-37{ }^{\circ} \mathrm{C}$ for 48 hours and of bacterial strains at $24-30{ }^{\circ} \mathrm{C}$ for 24 hours. The MIC was defined as the lowest concentration of the complexes at which maximum inhibition of growth is found for the microbial pathogens.

Agar well diffusion method. The YPDA or the YPAA was inoculated with the given fungi (Candida albicans and Cryptococcus neoformans) by spreading the fungal inoculum on the media plate. Wells ( $5 \mathrm{~mm}$ diameter) were punched in the agar and loaded with the $5 \mathrm{mg}$ $\mathrm{mL}^{-1}$ samples of the $\mathrm{Co}(\mathrm{II}), \mathrm{Ni}(\mathrm{II}), \mathrm{Cu}(\mathrm{II})$ and $\mathrm{Zn}$ (II) complexes. Blanks containing neat solvent i.e. DMSO (negative control) was also run parallel in the same plate. The plates were incubated at $37{ }^{\circ} \mathrm{C}$ for $48 \mathrm{~h}$ and antifungal activity determined by measuring the diameter of the zone of inhibition. The relative antifungal potency of the given preparation was calculated by comparing its zone of inhibition with that of the blank. Similarly, antibacterial activity was determined using NB agar inoculated by the given bacteria (Salmonella typhimurium and Escherichia coli) and was incubated for 24 hours at $25{ }^{\circ} \mathrm{C}$.

The elemental analyses were obtained from the Microanalytical Laboratory, using Elementar Vario EL III Carlo Erba elemental analyzer at Central Drug research Institute, Lucknow, India. The FT-IR spectra (4000-200 $\mathrm{cm}^{-1}$ ) were measured as $\mathrm{KBr} / \mathrm{CsI}$ discs using a Perkin-Elmer 2400 IR spectrophotometer. The ${ }^{1} \mathrm{H}$ NMR spectra were recorded on a Jeol Eclipse 400 n.m.r spectrometer in DMSO-d ${ }^{6}$ from King Saud University College of Sciences, Riyadh, Saudi Arabia. Metals and chloride were determined by volumetric and gravimetric methods, respectively. ${ }^{30,31}$ The electronic spectra of the complexes in DMSO were recorded on a Pye-Unicam 8800 spectrophotometer at room temperature. Magnetic susceptibility measurements were carried out using a Faraday balance at $25^{\circ} \mathrm{C}$. The EPR spectra of solid complexes at room temperature were recorded on a Jeol JES RE2X spectrometer fitted with $100 \mathrm{KHz}$ field modulation. The electrical conductivities of $10^{-3} \mathrm{~mol} \mathrm{~L}^{-1}$ solutions in DMSO were obtained on a digital APX 185 conductivity bridge equilibrated at $25 \pm 0.01{ }^{\circ} \mathrm{C}$.

\section{Acknowledgments}

The Chairman, Department of Chemistry, Aligarh Muslim University, is thanked for providing necessary facilities. The authors also thank the UGC, New Delhi, India vide Project No.F.12-116/2001 for financial support.

\section{References}

1. Sibert, J. W.; Cory, A. H.; Cory, J. G.; Chem. Commun. 2002, 154.

2. De Leon-Rodriguez, L. M.; Ortiz, A.; Weiner, A. L.; Zhang, S.; Kovacs, Z.; Kodadek, T.; Sherry, A. D.; J. Am. Chem. Soc. 2002, 124, 3514

3. Carvan, P.; Ellison, J. J.; McMurry, T. J.; Lauffer, R. B.; Chem. Rev. 1999, 99, 2293.

4. Beeby, A.; Bushby, L. M.; Maffeo, D.; Willams, J. A. G.; J. Chem. Soc., Dalton Trans. 2002, 48.

5. Burrows, C. J.; Muller, J. G.; Chem. Rev. 1998, 98, 1109.

6. Shih, H. C.; Tang, N.; Burrows, C. J.; Rokita, S. E.; J. Am. Chem. Soc. 1998, 120, 3284.

7. Moghaddas, S.; Hendry, P.; Geue, R. J.; Qin, C.; Bygott, A. M. T.; Sargeson, A. M.; Dixon, N. E.; J. Chem. Soc., Dalton Trans. 2000, 2085.

8. Robson, D. A.; Rees, L. H.; Mountford, P.; Schroder, M.; Chem. Commun. 2000, 1269.

9. Ehrlich, L. A.; Skrdla, P. J.; Jarrell, W. K.; Sibert, J. W.; Armstrong, N. R.; Saavedra, S. S.; Barrett, A. G. M.; Hoffman, B. M.; Inorg. Chem. 2000, 39, 3963.

10. Cameron, J. H.; Harvey, H. B.; Soutar, I.; J. Chem. Soc., Dalton Trans. 1992, 597.

11. Tweedy, H. E.; Alcock, N. W.; Matsumoto, N.; Padolik, P. A.; Stephenson, N. A.; Busch, D. H.; Inorg. Chem. 1990, 29, 616.

12. Wade, P. W.; Hancock, R. D.; J. Chem. Soc., Dalton Trans. 1990, 1323.

13. Peng, S. M.; Gordon, G. C.; Goedken, V. L.; Inorg. Chem. 1978, 17, 119.

14. Anastasi, D.; Curtis, N. F.; Gladkikh, D. P.; Goode, T. J. C.; Weatherburn, D. C.; Aust. J. Chem. 1998, 51, 673.

15. Hay, R. W.; Crayston, J. A.; Cromie, T. J.; Lightfoot, P.; De Alwis, D. C. L.; Polyhedron 1997, 16, 3557.

16. Ray, R. W.; Armstrong, J. M.; Hassan, M. M.; Transition Met. Chem. 1992, 17, 270.

17. Fabbrizi, L.; Lanfredi, A.; Pallavicini, P.; Perotti, A.; Tagliettei, A.; Ugazzoli, F.; J. Chem. Soc., Dalton Trans. 1991, 3263.

18. Cock, D. H.; Fenton, D. E.; Inorg. Chim. Acta 1977, 25, 95.

19. Wang, X.; Han, X.; Lu, W.; Liu, X.; Sun, D.; Synth. React. Inorg. Met.-Org. Chem. 1992, 22, 1169.

20. Shakir, M.; Islam, K. S.; Mohamed, A. K.; Shagufta, M.; Hassan, S. S.; Transition Met. Chem. 1999, 24, 577.

21. Rana, V. B.; Singh, P.; Singh, D. P.; Teotia, M. P.; Polyhedron 1982, 1, 377.

22. Lever, A. B. P. In Inorganic Electronic Spectroscopy; $2^{\text {nd }}$ ed., Elsevier: Amsterdam, 1984, ch. 9.

23. Ragunathan, R. G.; Bharadwaj, P. K.; J. Chem. Soc., Dalton Trans. 1992, 2417.

24. Ahuja, I.S.; Tripathi, S.; Indian J. Chem. 1991, 30A, 1060. 
25. Shakir, M.; Varkey, S. P.; Polyhedron 1994, 13, 791.

26. Proctor, I. M.; Hathaway, B. J.; Nicholls, P.; J. Chem. Soc. A 1968, 1678.

27. Schillinger, Y.; Luke, F. K.; Appl. Environ. Microbiol. 1989, 55, 1901.

28. National Committee for Clinical Laboratory Standards, www.nccls.org, 1995.
29. Chandra, S.; Gupta, L. K.; Spectrochim. Acta, Part A 2004, 60, 3079.

30. Reilly, C. N.; Schmid, R. W.; Sadak, F. A.; J. Chem. Educ. 1959, 36, 619.

31. Vogel, A. I. In A Text Book of Quantitative Inorganic Analysis; $3^{\text {rd }}$ ed., Longmans: London, 1961, p. 433.

Received: June 8, 2005 Published on the web: February 13, 2006 